\section{THE MINNEAPOLIS MEETING OF THE AMERICAN ASSOCIATION.}

THE sixty-second meeting of the American Association for the Advancement of Science was held on December 27-31, 1910, at Minneapolis, Minnesota, under the presidency of Dr. A. A. Michelson, of the University of Chicago.

The membership of the association lives for the most part in the large educational and scientific centres of the more eastern States, and, as a result, th large attendance always obtained at Boston, New York, Philadelphia, Baltimore, and Washington could not be expected during the Christmas holidays at a point so far removed as Minneapolis, which, by the way, is about thirty-six hours bv rail from New York or Washington. There was, therefore, an attendance of approximately between seven and eight hundred. As often happens, however, with the smaller meetings the interest was quite as keen, if not keener, and the quality of papers presented reached the usual high standard.

At the opening session, held on Tuesday night, December 27 , addresses of welcome were delivered by Dr. Cyrus C. Northrop, president of the University of Minnesota, and Mr. Wallace G. Nye, president of tho local Chamber of Commerce. President Michelson made an address in reply, after which the retiring president, Dr. David Starr Jordan, president of the Leland Stanford Junior University, delivered his address on "The Making of a Darwin," published in Nature on January I2. The people of Minneapolis were present in numbers and the audience at this session was very large.

All the meetings were held in the buildings of the University of Minnesota, one of the largest, most progressive and wealthiest of State universities. The handsome and admirably equipped buildings are concentrated in a reasonably compact campus, and no time was lost in going from one section to another. This was in striking relief from conditions existing in previous years. In Boston the meeting places were distributed through Harvard University, Massachusetts Institute of Technology. and Harvard Medical School, all very widely separated.

Apart from the opening meeting, there were only two other general sessions, one devoted to an address by Mr. A. B. Stickney, on the subject, "Should Practical Agriculture and the Physical Development of Childhood be Added to the Curriculum of the City Public Schools?" in the neighbouring city of Saint Paul, on Wednesday night; the other by Mr. William Alanson Bryan, on Thursday night, on the subject of "The Volcano Kilauea."

Probably on account of the distance involved, many of the affiliated societies which customarily meet with the American Association for the advancement of Science met at other cities, but the following were present and listened to excellent programmes :-

American Chemical Society, American Physical Society, American Psychological Association, Botanical Society of America, Botanists of the Central States, Entomological Society of America, American Association of Economic Entomologists, American Federation of Teachers of the Mathematical and Natural Sciences, Association of Horticultural Inspectors, American Mathematical Society (Chicago Section), American Microscopical Society, American Nature-study Society, American Phytopathological Society, Sullivant Moss Society, Western Philosophical Association, American Society of Zoologists (Central Branch).

Following the policy first formulated by the council three vears ago, and reiterated by the council this vear under formal resolution, the sections of the association, as a rule, did not present long programmes of shorter and more technical papers; but, aside from the addresses of the vice-presidents, devoted their time to the general discussion of topics of broad interest and conducted symposia on four subjects.

The addresses of the vice-presidents (presidents of sections) were as follows :-

A (Mathematics and Astronomy), Ernest W. Brown, Yale University, New Haven, Conn., "The Relations of Jupiter with the Asteroids." B (Physics), Louis A. Bauer, Carnegie Institution, Washington, D.C., "The Broader Aspects of Research in Terrestrial Magnetism." C (Chemistry), William McPherson, Ohio State University, Columbus, Ohio, "The Formation of Carbohydrates in the Vegetable Kingdom." D (Mechanical Science and Engineering), John F. Hayford, College of Engineering, Evanston, Illinois, "The Relations of Isostasy to Geodesy, Geology, and Geophysics." E (Geology and Geography), Reginald W. Brock, Geological Survey of Canada, Kingston, Canada, "Northern Canada." F (Zoology), William E. Ritter, Marine Biological Laboratory, San Diego, California, "The Controversy between Mechanism and Vitalism : Can it be Ended?" I (Social and Economic Science), Byron W. Holt, New York, N.Y., "Causes and Effects of High Land Values." $\mathrm{K}$,(Physiology and Experimental Medicine), Charles Sedgwick Minot, Harvard Medical School, Boston, Massachusetts, "The Method of Science."

The principal symposia were as follows :-Section $\mathrm{K}$ presented a series of excellent papers by well-known experts on "Disease Due to Filterable Organisms," including two papers on the mysterious Rocky Mountain spotted fever, another on "Acute Anterior Poliomyslitis," and another on "Yellow Fever, Dengue Fever, and Pappataci Fever." In the same symposium, general attention was given to animal diseases, plant diseases, and experimental diseases. The diseases of domestic animals considered were rabies and hog cholera.

Under the Section of Mechanical Science and Engineering, an important symposium was held on the subject of aerronautics, the papers for the most part being technical; but the list included an "Appreciation of Dr. Octave Chanute and $\mathrm{His}$ Work in Engineering and Aëronautics," an historical paper on the "Early Attempts to Navigate the Air," a suggested programme of aëronautical research at the colleges, and a paper on "Technical Education in Aëronautics."

Many joint programmes were held between the sections and the affiliated societies. An important conference on botany teaching was held by all of the botanists present, and the question of the water supply of Minnesota was discussed by the geologists. Questions of sewage pollution and the smoky atmosphere of western cities and many other practical topics were discussed in the Section of Chemistry. Section L (Education) joined with the American Psychological Association in discussing general questions relating to school children.

No actions of great importance were taken by the council aside from the resolution looking to the generalising and broadening of the sections and the restriction of purely technical programmes to the affiliated societies.

Two British subjects, and members of the British Association, were in attendance and were made honorary members for the meeting. They were Dr. Marie C. Stopes, of the University, Manchester, and Prof. A. H. R. Buller, of the Universitv of Manitoba.

The general committee designated Washington as the place for the next meeting, with recommendations that Cleveland and Toronto be chosen in the succession indicated for following meetings.

The following officers were elected for the Washington meeting :-

NO. 2 I 52 , VOL. 85 ! 
President-Charles E. Bessey, University of Nebraska, Lincoln, Nebraska.

Vice-presidents.-A, Mathematics and Astronomy, Edwin B. Frost, Yerkes Observatory, Williams Bay, Wisconsin; B, Physics, Robert A. Millikan, University of Chicago, Chicago, Illinois; C, Chemistry, Frank K. Cameron, U.S. Department of Agriculture, Washington, D.C.; D, Mechanical Science and Engineering, Charles S. Howe, Case School of Applied Science, Cleveland, Ohio; E, Geology and Geography, Bohumil Shimek, State University of Iowa, Iowa City, lowa; F, Zoology, Henry F. Nachtrieb, University of Minnesota, Minneapolis, Minnesota; G, Botany, Frederick C. Newcombe, University of Michigan, Ann Arbor, Michigan; H, Anthropology and Psychology, George T. Ladd, Yale University, New Haven, Conn.; I, Social and Economic Science (vacant); $\mathrm{K}$, Physiology and Experimental Science, William T. Porter, Harvard Medical School, Boston, Mass.; L, Education, Edward L. Thorndike, Columbia University, New York, N.Y.

Permanent Secretary.-L. O. Howard, Smithsonian Institution, Washington, D.C.

General Secretary.-John Zeleny, University of Minnesota, Minneapolis, Minnesota.

Secretary of the Council.-Theodore S. Palmer, U.S. Department of Agriculture, Washington, D.C.

Secretaries of the Sections.-A, Mathematics and Astro nomy, George A. Miller, University of Illinois, Urbana, Illinois; B, Physics, Alfred D. Cole, Ohio State University, Columbus, Ohio; $\mathrm{C}$, Chemistry, Charles $\mathrm{H}$. Herty, University of North Carolina, Chapel Hill, N.C. D, Mechanical Science and Engineering, George W. Bissell, Michigan Agricultural College, East Lansing, Mich.; E, Geology and Geography, F. P. Gulliver, Norwich, Conn.; F, Zoology, Maurice A. Bigelow, Columbia University, New York, N.Y.; G, Botany, Henry C. Cowles, University of Chicago, Chicago, Illinois; $\mathrm{H}$, Anthropology and Psychology, George Grant MacCurdy, Yale University Museum, New Haven, Conn.; I, Social and Economic Science, Fred C. Croxton, I229 Girard Street, Washington, D.C.; K, Physiology and Experimental Medicine, George T. Kemp, 8 West 25th Street, Baltimore, Maryland; L, Education, Charles Riborg Mann, University of Chicago, Chicago, Illinois.

Treasurer.-R. S. Woodward, Carnegie Institution, Washington, D.C.

\section{SCIENCE AND POTTERY.'}

THE English Ceramic Society, founded about 1 ten years ago, had its origin in a belated attempt, made by a few enlightened manufacturers, to introduce scientific method into the conduct of one of our most important industries. There is a proverbial connection between the potter and his thumb, and in no other leading manufacture in this country is the rule of thumb so dominant or so repressive as it is in that of pottery. The ceramic art as practised in England is for the most part empirical, and is therefore highly conservative; changes are few and progress is correspondingly slow. At the same time, in certain respects, the industry has reached a high degree of mechanical perfection. English china is a product sui generis, and its merits are widely recognised, even by those who decline to regard it as a variety of porcelain. In the manufacture of the highest qualities of earthenware no nation has hitherto surpassed us. But signs are not wanting that our supremacy is challenged, and each succeeding decade sees the struggle becoming more and more acute. The industry is, in fact, between the upper and the nether millstones of conflicting tariff systems. Industrial conditions in the Potteries are, in some respects, without parallel in any other manufacturing district. In

1 Transactions of the English Ceramic Society. Vol. ix. Session rgog-ro (Stoke-on-Trent. Staffordshire : Published by the Society; Longton : Hughs and Harher, Ltd., igro.)

No. 2 I 52 , VOL. 85 ] no other staple trade of like magnitude is to be found so numerous a class of small manufacturers-persons of little or no capital and employing few hands-some of them no more than the members of their own families. These are for the most part ignorant of anything beyond the ordinary technique of their art. Even in the case of larger concerns, it was, until of late years, rare to meet with any evidence of practical recognition of the scientific principles underlying the industry. Such a condition of things cannot possibly tend to development in the art itself, or to improvement in the welfare of the workers engaged in it.

Ceramics is a branch of applied chemistry and physics, of chemical engineering in its most comprehensive sense. That this fact is beginning to be slowly appreciated may, we think, be inferred from the gradual increase in the number of the members of the English Ceramic Society. The society started in I900-I with 29 members; in 1909-10 its numbers were $26 \mathrm{I}$, but of these, it ought to be said, a certain fraction are engaged in American and Continental factories. But, after all, this growth in numerical strength is hardly commensurate with the value and importance of the society's objects, or with the influence it may be expected to exercise upon the development of the industry with which it is concerned. In the United Kingdom there are some $55^{\circ}$ potteries; of these 329 are concentrated in the group of towns known as the North Staffordshire Potteries. It is not unreasonable to expect that in the case of an institution centrally situated and in close proximity to Burslem, Fenton, Hanley, Longton, and Tunstall there would, after ten years of existence, be a membership equal at least to the number of factories in the neighbourhood. That such is not the case is only one more instance of the supineness and indifference of our manufacturers, as a class, to the bearing of physical science, its methods and its teaching, upon their industries.

Of the general character of the twenty-two contributions to the scientific work of the society contained in this volume we have nothing but commendation to offer. They all bear directly on problems of practical interest to the potter. The papers of $\mathrm{Mr}$. Fowler on the control of kiln and oven gases; of Messrs. Cobb and King on the fluxing power of the common oxides; the papers by Dr. Mellor on cylinder grinding, vitrification of clays, surface factors, softening temperatures of lead silica glazes, and the two excellent papers by Mr. Thomason, on the toxic possibilities of fritted lead glazes and on white lead and plumbism are of permanent value as additions to ceramic literature. The latter papers are of special interest at the moment in relation to the question of lead-poisoning in pottery manufacture. Mr. Thomason points out that the official returns from such factories as are working under the 5 per cent. standard of solubility, as defined by the method prescribed by $\mathrm{Sir}$ Edward Thorpe, and adopted in the Home Office special rules, show no cases of plumbism amongst workers in the prepared glazes, and that the information available from the Continent is to a similar effect. It has been objected to this method that it bears no real analogy to what actually goes on in the human system. Mr. Thomason effectually meets this objection. After a careful experimental inquiry of which full details are given in the papers, and in which, so far as possible, all the conditions known to occur in the animal body were separately and collectively studied, Mr. Thomason concludes that the solubility of a glaze in the stomach is properly gauged by the official method, and that the figures so obtained are fair statements of its toxic possibilities.

These papers were evidently not verv pleasant hear- 